\title{
Combustion of Toluene Catalyzed by $\mathrm{Pt} / \mathrm{Co}_{3} \mathrm{O}_{4} / \mathrm{CeO}_{2}-\mathrm{ZrO}_{2}-\mathrm{SnO}_{2} / \gamma-\mathrm{Al}_{2} \mathrm{O}_{3}$
}

\author{
Min Yeong Kim ${ }^{1}$, Tomoya Kamata ${ }^{1}$, Toshiyuki Masui ${ }^{1} \&$ Nobuhito Imanaka $^{1}$ \\ ${ }^{1}$ Department of Applied Chemistry, Faculty of Engineering, Osaka University, Osaka, Japan \\ Correspondence: Nobuhito Imanaka, Department of Applied Chemistry, Faculty of Engineering, Osaka \\ University, 2-1 Yamadaoka, Suita, Osaka 565-0871, Japan. Tel: 81-6-6879-7352. Fax: 81-6-6879-7354. E-mail: \\ imanaka@chem.eng.osaka-u.ac.jp
}

Received: February 4, 2013 Accepted: April 6, 2013 Online Published: April 15, 2013

doi:10.5539/jmsr.v2n3p51 URL: http://dx.doi.org/10.5539/jmsr.v2n3p51

\begin{abstract}
A $1 \mathrm{wt} \% \mathrm{Pt} / \mathrm{Co}_{3} \mathrm{O}_{4} / \mathrm{CeO}_{2}-\mathrm{ZrO}_{2}-\mathrm{SnO}_{2} / \gamma-\mathrm{Al}_{2} \mathrm{O}_{3}$ catalyst was prepared to realize complete combustion of toluene at the lowest temperature possible without excessive use of platinum particles. The addition of $\mathrm{Co}_{3} \mathrm{O}_{4}$ to $\mathrm{Pt} / \mathrm{CeO}_{2}-\mathrm{ZrO}_{2}-\mathrm{SnO}_{2} / \gamma-\mathrm{Al}_{2} \mathrm{O}_{3}$ as a promoter was effective in decreasing the amount of platinum without significant reduction in the catalytic activity. The highest activity for the combustion of toluene was observed using the $1 \mathrm{wt} \% \mathrm{Pt} / 11 \mathrm{wt} \% \mathrm{Co}_{3} \mathrm{O}_{4} / 16 \mathrm{wt} \% \mathrm{Ce}_{0.62} \mathrm{Zr}_{0.20} \mathrm{Sn}_{0.18} \mathrm{O}_{2.0} / \gamma-\mathrm{Al}_{2} \mathrm{O}_{3}$ catalyst, and despite a smaller platinum loading in the present catalyst, toluene was completely oxidized to carbon dioxide and water vapor at a lower temperature of $160{ }^{\circ} \mathrm{C}$ compared to that using $5 \mathrm{wt} \% \mathrm{Pt} / \gamma-\mathrm{Al}_{2} \mathrm{O}_{3}$ at $170{ }^{\circ} \mathrm{C}$.
\end{abstract}

Keywords: volatile organic compounds, catalytic combustion, toluene, oxidation, rare earth oxide

\section{Introduction}

Some examples of volatile organic compounds (VOCs) are aldehydes, ketones, and other light weight hydrocarbons. Since they have relatively high vapor pressures under ambient conditions, they vaporize and diffuse easily into the atmosphere. Some VOCs are harmful to human health and the environment. They have been known to cause sick building syndrome, multiple chemical sensitivity, and air pollution such as photo-chemical smog and ground-level ozone (Atkinson et al., 2003; Ryerson et al., 2001).

Among the VOCs, toluene is widely used as an organic solvent for paints, printing inks, adhesives, and antiseptics due to its excellent ability to dissolve organic substances. Conseuently, in order to avoid the above-mentioned harmful effects, it is necessary to reduce the amount of toluene released into the atmosphere as much as possible.

For effective reduction, several methods have been proposed such as catalytic combustion (Sungkono et al., 1997), flame combustion (Hamins et al., 1987), catalytic decomposition using ozone and plasma (Harling et al., 2009), photocatalytic decomposition (Einaga et al., 2002), and the adsorbent-based method (Hauxell et al., 1968). Among these methods, complete catalytic combustion of toluene into carbon dioxide and water vapor at moderate temperatures is an ecologically simple and clean technology to eliminate toluene (Spivey, 1987). A number of combustion catalysts for the reduction of toluene have been reported. However, it is difficult to accomplish complete combustion of toluene at low temperatures. Moreover, the catalyst needs to be heated to at least $200{ }^{\circ} \mathrm{C}$ (Imanaka et al., 2011; Saqer et al., 2009).

On the contrary, in our previous studies, we found that a combination of platinum and a solid that can supply reactive oxygen molecules below $100{ }^{\circ} \mathrm{C}$ (Imanaka et al., 2005, 2007, 2011; Masui et al., 2006, 2007; Minami et al., 2006) was significantly effective in inducing the oxidation of VOCs by oxygen pullover from $\mathrm{Ce}_{0.64} \mathrm{Zr}_{0.16} \mathrm{Bi}_{0.20} \mathrm{O}_{1.90} / \gamma-\mathrm{Al}_{2} \mathrm{O}_{3}$ to platinum nanoparticles (Imanaka et al., 2008, 2009). In fact, we found that a $7 \mathrm{wt} \% \mathrm{Pt} / 16 \mathrm{wt} \% \mathrm{Ce}_{0.64} \mathrm{Zr}_{0.16} \mathrm{Bi}_{0.20} \mathrm{O}_{1.90} / \gamma-\mathrm{Al}_{2} \mathrm{O}_{3}$ catalyst can completely oxidize toluene at $120{ }^{\circ} \mathrm{C}$ (Masui et al., 2010). Furthermore, we demonstrated in our recent study that a $10 \mathrm{wt} \% \mathrm{Pt} / 16 \mathrm{wt} \% \mathrm{Ce}_{0.68} \mathrm{Zr}_{0.17} \mathrm{Sn}_{0.15} \mathrm{O}_{2.0} / \gamma-\mathrm{Al}_{2} \mathrm{O}_{3}$ catalyst can completely oxidize toluene at a temperature as low as $110{ }^{\circ} \mathrm{C}$ (Yasuda et al., 2012). However, a relatively large amount of platinum was supported on these catalysts, leading to high cost production from a practical application standpoint. Therefore, it is necessary to reduce the precious metal content in the catalysts as much as possible with no significant decrease in the catalytic activity. 
To realize such advanced catalysts, we focused on cobalt oxide $\left(\mathrm{Co}_{3} \mathrm{O}_{4}\right)$ as a promoter to facilitate the oxidation of toluene without excessive use of platinum, since $\mathrm{Co}_{3} \mathrm{O}_{4}$ was reported to have the highest catalytic activity for VOCs oxidation among several transition metal oxides investigated (Chianelli et al., 2009; Lamonier et al., 2007; Liotta et al., 2009; Pedrosa et al., 2003; Rybak et al., 2011; Wyrwalski et al., 2010). In this study, the amount of platinum was decreased to $1 \mathrm{wt} \%$ and $\mathrm{Co}_{3} \mathrm{O}_{4}$ was employed as a promoter: $1 \mathrm{wt} \% \mathrm{Pt} / 11 \mathrm{wt} \% \mathrm{Co}_{3} \mathrm{O}_{4} / 16 \mathrm{wt} \%$ $\mathrm{CeO}_{2}-\mathrm{ZrO}_{2}-\mathrm{SnO}_{2} / \gamma-\mathrm{Al}_{2} \mathrm{O}_{3}$ catalysts were prepared and the effect of $\mathrm{Co}_{3} \mathrm{O}_{4}$ on the activity of toluene oxidation was investigated. Furthermore, the catalyst composition was optimized to give the highest activity.

\section{Experimental}

A $\mathrm{Ce}_{0.62} \mathrm{Zr}_{0.20} \mathrm{Sn}_{0.18} \mathrm{O}_{2.0} / \gamma-\mathrm{Al}_{2} \mathrm{O}_{3}$ support was synthesized by co-precipitation and impregnation methods: the $\mathrm{Ce}_{0.62} \mathrm{Zr}_{0.20} \mathrm{Sn}_{0.18} \mathrm{O}_{2.0}$ was synthesized by co-precipitation and the subsequent deposition on $\gamma-\mathrm{Al}_{2} \mathrm{O}_{3}$ was carried out by impregnation. $\mathrm{SnC}_{2} \mathrm{O}_{4}$ was dissolved in a mixture of $1.0 \mathrm{~mol} \mathrm{~L}^{-1} \mathrm{Ce}\left(\mathrm{NO}_{3}\right)_{3}$ and $0.1 \mathrm{~mol} \mathrm{~L}^{-1} \mathrm{ZrO}\left(\mathrm{NO}_{3}\right)_{2}$ aqueous solutions in a stoichiometric ratio, and then the mixture was impregnated on commercially available $\gamma-\mathrm{Al}_{2} \mathrm{O}_{3}$ (DK Fine, AA-300). The $\mathrm{Ce}_{0.62} \mathrm{Zr}_{0.20} \mathrm{Sn}_{0.18} \mathrm{O}_{2.0}$ content was adjusted to $16 \mathrm{wt} \%$ of the total support to optimize the oxygen release ability (Yasuda et al., 2012). The $\mathrm{pH}$ of the aqueous mixture was adjusted to 11 by dropwise addition of aqueous ammonia (5\%), whereby the $\mathrm{Ce}_{0.62} \mathrm{Zr}_{0.20} \mathrm{Sn}_{0.18} \mathrm{O}_{2.0}$ particles were precipitated on the surface of $\gamma-\mathrm{Al}_{2} \mathrm{O}_{3}$. After stirring for $12 \mathrm{~h}$ at room temperature, the resulting $\mathrm{Ce}_{0.62} \mathrm{Zr}_{0.20} \mathrm{Sn}_{0.18} \mathrm{O}_{2.0} / \gamma-\mathrm{Al}_{2} \mathrm{O}_{3}$ support was collected by filtration, washed several times with deionized water, and then dried at $80{ }^{\circ} \mathrm{C}$ for $6 \mathrm{~h}$. The sample was ground in an agate mortar and calcined at $600^{\circ} \mathrm{C}$ for $1 \mathrm{~h}$ in an ambient atmosphere.

Supported cobalt oxide catalysts $\left[x w t \% \mathrm{Co}_{3} \mathrm{O}_{4} / 16 \mathrm{wt} \% \mathrm{Ce}_{0.62} \mathrm{Zr}_{0.20} \mathrm{Sn}_{0.18} \mathrm{O}_{2.0} / \gamma-\mathrm{Al}_{2} \mathrm{O}_{3}(x=7,11\right.$, and 14)] were prepared by mixing a $0.1 \mathrm{~mol} \mathrm{~L} \mathrm{~L}^{-1} \mathrm{Co}\left(\mathrm{NO}_{3}\right)_{3}$ aqueous solution with the $\mathrm{Ce}_{0.62} \mathrm{Zr}_{0.20} \mathrm{Sn}_{0.18} \mathrm{O}_{2.0} / \gamma-\mathrm{Al}_{2} \mathrm{O}_{3}$ support. After mixing, the homogeneous samples were evaporated to dryness at $80{ }^{\circ} \mathrm{C}$ for $12 \mathrm{~h}$, and then calcined at $500{ }^{\circ} \mathrm{C}$ for $1 \mathrm{~h}$ in an ambient atmosphere.

A supported platinum catalyst $\left(1 \mathrm{wt} \% \mathrm{Pt} / \mathrm{xwt} \% \mathrm{Co}_{3} \mathrm{O}_{4} / 16 \mathrm{wt} \% \mathrm{Ce}_{0.62} \mathrm{Zr}_{0.20} \mathrm{Sn}_{0.18} \mathrm{O}_{2.0} / \gamma-\mathrm{Al}_{2} \mathrm{O}_{3}\right)$ was prepared by impregnating the $x \mathrm{wt} \% \mathrm{Co}_{3} \mathrm{O}_{4} / 16 \mathrm{wt} \% \mathrm{Ce}_{0.62} \mathrm{Zr}_{0.20} \mathrm{Sn}_{0.18} \mathrm{O}_{2.0} / \gamma-\mathrm{Al}_{2} \mathrm{O}_{3}$ support, in which the amount of $\mathrm{Co}_{3} \mathrm{O}_{4}(x)$ was optimized to give the highest activity, with a $4 \mathrm{wt} \%$ platinum colloid stabilized with polyvinylpyrrolidone in a water solvent (Tanaka Kikinzoku Kogyo Co., Ltd.). After impregnation, the sample was dried at $80^{\circ} \mathrm{C}$ for $12 \mathrm{~h}$, and then calcined at $450{ }^{\circ} \mathrm{C}$ or $500{ }^{\circ} \mathrm{C}$ for $4 \mathrm{~h}$. For references, a $1 \mathrm{wt} \% \mathrm{Pt} / 16 \mathrm{wt} \% \mathrm{Ce}_{0.68} \mathrm{Zr}_{0.17} \mathrm{Sn}_{0.15} \mathrm{O}_{2.0} / \gamma-\mathrm{Al}_{2} \mathrm{O}_{3}$ catalyst without $\mathrm{Co}_{3} \mathrm{O}_{4}$ and a $5 \mathrm{wt} \% \mathrm{Pt} / \gamma-\mathrm{Al}_{2} \mathrm{O}_{3}$ catalyst were also prepared using the same procedure.

The sample compositions were analyzed using an X-ray fluorescence spectrometer (XRF; Rigaku, ZSX-100e). The crystal structures of the catalysts were identified by X-ray powder diffraction (XRD; Rigaku, SmartLab) using $\mathrm{Cu}-\mathrm{K} \alpha$ radiation $(40 \mathrm{kV}, 30 \mathrm{~mA})$. The Brunauer-Emmett-Teller (BET) specific surface area was measured by nitrogen adsorption at $-196{ }^{\circ} \mathrm{C}$ and pore size distribution (PSD) plots were obtained by Barrett-Joyner-Halenda (BJH) method using the cylindrical pore model (Micromeritics Tristar 3000). X-ray photoelectron spectroscopy (XPS; ULVAC 5500MT) measurement was performed at room temperature using $\mathrm{Mg}-\mathrm{K} \alpha$ radiation $(1253.6 \mathrm{eV})$. The effect of charging on the binding energies was corrected with respect to the $\mathrm{C}$ $1 \mathrm{~s}$ peak at $284.6 \mathrm{eV}$. Transmission electron microscopic images were also taken with an accelerating voltage of $200 \mathrm{kV}$ (TEM; Hitachi H-800). Temperature programmed reduction (TPR) measurements were carried out under a flow of pure $\mathrm{H}_{2}\left(80 \mathrm{~mL} \mathrm{~min}^{-1}\right)$ at a heating rate of $5 \mathrm{~K} \mathrm{~min}^{-1}$ using a gas chromatograph with a thermal conductivity detector (TCD; Shimadzu GC-8AIT). Following the TPR experiments, the total oxygen storage capacity (OSC) was measured using a pulse-injection method at $427^{\circ} \mathrm{C}(700 \mathrm{~K})$.

The oxidation activity for toluene was tested in a conventional fixed-bed flow reactor consisting of a 10 -mm-diameter quartz glass tube. The feed gas was composed of $0.09 \mathrm{vol} \%$ toluene in an air balance and the rate was $20 \mathrm{~mL} \mathrm{~min}{ }^{-1}$ over $0.1 \mathrm{~g}$ of the catalyst [space velocity (S.V.) $=12,000 \mathrm{~L} \mathrm{~kg}^{-1} \mathrm{~h}^{-1}$ ]. Prior to the measurements, the catalyst was heated at $200{ }^{\circ} \mathrm{C}$ for $2 \mathrm{~h}$ in a flow of $\operatorname{Ar}\left(20 \mathrm{~mL} \mathrm{~min}^{-1}\right)$ to remove water molecules adsorbed on the surface of the catalyst. The catalytic activity was evaluated in terms of toluene conversion. The gas composition after the reaction was analyzed using a gas chromatograph with a flame ionization detector (FID; Shimadzu GC-8AIF) and a gas chromatograph-mass spectrometer (GC-Mass; Shimadzu GCMS-QP2010 Plus).

\section{Results and Discussion}

Figure 1 shows XRD patterns of the $16 \mathrm{wt} \% \mathrm{Ce}_{0.62} \mathrm{Zr}_{0.20} \mathrm{Sn}_{0.18} \mathrm{O}_{2.0} / \gamma-\mathrm{Al}_{2} \mathrm{O}_{3}\left(\mathrm{CZS} / \mathrm{Al}_{2} \mathrm{O}_{3}\right), 7 \mathrm{wt} \% \mathrm{Co}_{3} \mathrm{O}_{4} / 16 \mathrm{wt} \%$ $\mathrm{Ce}_{0.62} \mathrm{Zr}_{0.20} \mathrm{Sn}_{0.18} \mathrm{O}_{2.0} / \gamma-\mathrm{Al}_{2} \mathrm{O}_{3}\left(7 \mathrm{Co} / \mathrm{CZS} / \mathrm{Al}_{2} \mathrm{O}_{3}\right), \quad 11 \mathrm{wt} \% \mathrm{Co}_{3} \mathrm{O}_{4} / 16 \mathrm{wt} \% \mathrm{Ce}_{0.62} \mathrm{Zr}_{0.20} \mathrm{Sn}_{0.18} \mathrm{O}_{2.0} / \gamma-\mathrm{Al}_{2} \mathrm{O}_{3} \quad(11 \mathrm{Co} / \mathrm{CZS} /$ $\left.\mathrm{Al}_{2} \mathrm{O}_{3}\right)$, and $15 \mathrm{wt} \% \mathrm{Co}_{3} \mathrm{O}_{4} / 16 \mathrm{wt} \% \mathrm{Ce}_{0.62} \mathrm{Zr}_{0.20} \mathrm{Sn}_{0.18} \mathrm{O}_{2.0} / \gamma-\mathrm{Al}_{2} \mathrm{O}_{3}\left(15 \mathrm{Co} / \mathrm{CZS} / \mathrm{Al}_{2} \mathrm{O}_{3}\right)$ catalysts. The XRD results for the $\mathrm{CZS} / \mathrm{Al}_{2} \mathrm{O}_{3}$ support show only peaks corresponding to the cubic fluorite-type oxide, $\mathrm{Co}_{3} \mathrm{O}_{4}$, and $\gamma-\mathrm{Al}_{2} \mathrm{O}_{3}$, and no crystalline impurities were observed. The diffraction peaks assigned to the cubic fluorite type structure were 
steady and no peak shift was observed regardless of the amount of cobalt oxide, indicating that $\mathrm{Co}_{3} \mathrm{O}_{4} \mathrm{was}$ supported on the surface of the $\mathrm{CZS} / \mathrm{Al}_{2} \mathrm{O}_{3}$ support without forming solid solutions with $\mathrm{CZS}$ or $\gamma-\mathrm{Al}_{2} \mathrm{O}_{3}$.

BET specific surface areas of the $\mathrm{CZS} / \mathrm{Al}_{2} \mathrm{O}_{3}, 7 \mathrm{Co} / \mathrm{CZS} / \mathrm{Al}_{2} \mathrm{O}_{3}, 11 \mathrm{Co} / \mathrm{CZS} / \mathrm{Al}_{2} \mathrm{O}_{3}$, and $15 \mathrm{Co} / \mathrm{CZS} / \mathrm{Al}_{2} \mathrm{O}_{3}$ catalysts are summarized in Table 1. The BET specific surface areas of the cobalt-supported catalysts were smaller than that of $\mathrm{CZS} / \mathrm{Al}_{2} \mathrm{O}_{3}$, and they decreased with increasing $\mathrm{Co}_{3} \mathrm{O}_{4}$ content. These results suggest that some of the $\mathrm{Co}_{3} \mathrm{O}_{4}$ particles are supported in the pores of $\mathrm{CZS} / \mathrm{Al}_{2} \mathrm{O}_{3}$.

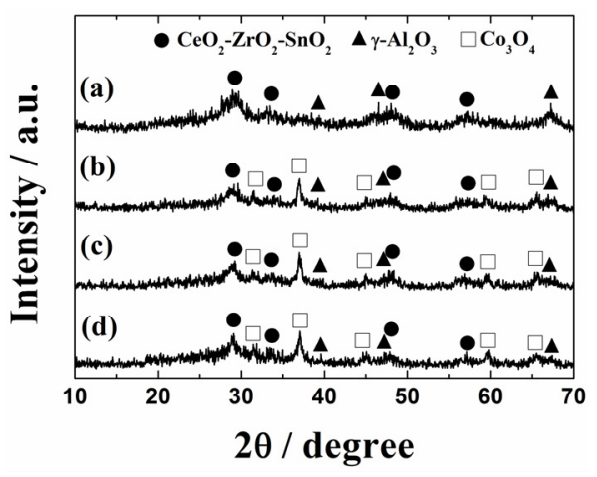

Figure 1. XRD patterns of the (a) $16 \mathrm{wt} \% \mathrm{Ce}_{0.62} \mathrm{Zr}_{0.20} \mathrm{Sn}_{0.18} \mathrm{O}_{2.0} / \gamma-\mathrm{Al}_{2} \mathrm{O}_{3}$,

(b) $7 \mathrm{wt} \% \mathrm{Co}_{3} \mathrm{O}_{4} / 16 \mathrm{wt} \% \mathrm{Ce}_{0.62} \mathrm{Zr}_{0.20} \mathrm{Sn}_{0.18} \mathrm{O}_{2.0} / \gamma-\mathrm{Al}_{2} \mathrm{O}_{3}$, (c) $11 \mathrm{wt} \% \mathrm{Co}_{3} \mathrm{O}_{4} / 16 \mathrm{wt} \% \mathrm{Ce}_{0.62} \mathrm{Zr}_{0.20} \mathrm{Sn}_{0.18} \mathrm{O}_{2.0} / \gamma-\mathrm{Al}_{2} \mathrm{O}_{3}$, and (d) $15 \mathrm{wt} \% \mathrm{Co}_{3} \mathrm{O}_{4} / 16 \mathrm{wt} \% \mathrm{Ce}_{0.62} \mathrm{Zr}_{0.20} \mathrm{Sn}_{0.18} \mathrm{O}_{2.0} / \gamma-\mathrm{Al}_{2} \mathrm{O}_{3}$ catalysts $\left(\bullet: \mathrm{CeO}_{2}-\mathrm{ZrO}_{2}-\mathrm{SnO}_{2}, \mathbf{\Delta}: \gamma-\mathrm{Al}_{2} \mathrm{O}_{3}, \square: \mathrm{Co}_{3} \mathrm{O}_{4}\right)$

Table 1. Composition and BET surface area of the catalysts

\begin{tabular}{ccc}
\hline Catalyst & Catalyst composition & $\begin{array}{c}\text { BET surface area } \\
\left(\mathrm{m}^{2} \mathrm{~g}^{-1}\right)\end{array}$ \\
\hline $\mathrm{CZS} / \mathrm{Al}_{2} \mathrm{O}_{3}$ & $16 \mathrm{wt} \% \mathrm{Ce}_{0.62} \mathrm{Zr}_{0.20} \mathrm{Sn}_{0.18} \mathrm{O}_{2.0} / \gamma-\mathrm{Al}_{2} \mathrm{O}_{3}$ & 190 \\
$7 \mathrm{Co} / \mathrm{CZS} / \mathrm{Al}_{2} \mathrm{O}_{3}$ & $7 \mathrm{wt} \% \mathrm{Co}_{3} \mathrm{O}_{4} / 16 \mathrm{wt} \% \mathrm{Ce}_{0.62} \mathrm{Zr}_{0.20} \mathrm{Sn}_{0.18} \mathrm{O}_{2.0} / \gamma-\mathrm{Al}_{2} \mathrm{O}_{3}$ & 151 \\
$11 \mathrm{Co} / \mathrm{CZS} / \mathrm{Al}_{2} \mathrm{O}_{3}$ & $11 \mathrm{wt} \% \mathrm{Co}_{3} \mathrm{O}_{4} / 16 \mathrm{wt} \% \mathrm{Ce}_{0.62} \mathrm{Zr}_{0.20} \mathrm{Sn}_{0.18} \mathrm{O}_{2.0} / \gamma-\mathrm{Al}_{2} \mathrm{O}_{3}$ & 141 \\
$15 \mathrm{Co} / \mathrm{CZS} / \mathrm{Al}_{2} \mathrm{O}_{3}$ & $15 \mathrm{wt} \% \mathrm{Co}_{3} \mathrm{O}_{4} / 16 \mathrm{wt} \% \mathrm{Ce}_{0.62} \mathrm{Zr}_{0.20} \mathrm{Sn}_{0.18} \mathrm{O}_{2.0} / \gamma-\mathrm{Al}_{2} \mathrm{O}_{3}$ & 139 \\
$1 \mathrm{Pt} / 11 \mathrm{Co} / \mathrm{Al}_{2} \mathrm{O}_{3}$ & $1 \mathrm{wt} \% \mathrm{Pt} / 11 \mathrm{wt} \% \mathrm{Co}_{3} \mathrm{O}_{4} / \gamma-\mathrm{Al}_{2} \mathrm{O}_{3}$ & 166 \\
$1 \mathrm{Pt} / \mathrm{CZS} / \mathrm{Al}_{2} \mathrm{O}_{3}$ & $1 \mathrm{wt} \% \mathrm{Pt} / 16 \mathrm{wt} \% \mathrm{Ce}_{0.62} \mathrm{Zr}_{0.20} \mathrm{Sn}_{0.18} \mathrm{O}_{2.0} / \gamma-\mathrm{Al}_{2} \mathrm{O}_{3}$ & 176 \\
$1 \mathrm{Pt} / 11 \mathrm{Co} / \mathrm{CZS} / \mathrm{Al}_{2} \mathrm{O}_{3}$ & $1 \mathrm{wt} \% \mathrm{Pt} / 11 \mathrm{wt} \% \mathrm{Co}_{3} \mathrm{O}_{4} / 16 \mathrm{wt} \% \mathrm{Ce}_{0.62} \mathrm{Zr}_{0.20} \mathrm{Sn}_{0.18} \mathrm{O}_{2.0} / \gamma-\mathrm{Al}_{2} \mathrm{O}_{3}$ & 131 \\
\hline
\end{tabular}

Figure 2 depicts temperature dependencies of toluene oxidation over the $7 \mathrm{Co} / \mathrm{CZS} / \mathrm{Al}_{2} \mathrm{O}_{3}, 11 \mathrm{Co} / \mathrm{CZS} / \mathrm{Al}_{2} \mathrm{O}_{3}$, and $15 \mathrm{Co} / \mathrm{CZS} / \mathrm{Al}_{2} \mathrm{O}_{3}$ catalysts. Toluene was completely oxidized into $\mathrm{CO}_{2}$ and water vapor, and no $\mathrm{CO}$ and toluene-derived compounds were detected as by-products with a gas chromatograph. The toluene oxidation activity depends on the catalyst composition, and the highest activity was obtained for $11 \mathrm{Co} / \mathrm{CZS} / \mathrm{Al}_{2} \mathrm{O}_{3}$. However, the activity decreased with increasing $\mathrm{Co}_{3} \mathrm{O}_{4}$ content beyond the optimum amount, probably due to $\mathrm{Co}_{3} \mathrm{O}_{4}$ agglomeration and particle growth. Toluene oxidation activity of the optimum $11 \mathrm{Co} / \mathrm{CZS} / \mathrm{Al}_{2} \mathrm{O}_{3}$ catalyst was initially observed at $100^{\circ} \mathrm{C}$, and complete oxidation of toluene was confirmed at $300{ }^{\circ} \mathrm{C}$. Unfortunately, this temperature was higher than that of $10 \mathrm{wt} \% \mathrm{Pt} / 16 \mathrm{wt} \% \mathrm{Ce}_{0.68} \mathrm{Zr}_{0.17} \mathrm{Sn}_{0.15} \mathrm{O}_{2.00} / \gamma-\mathrm{Al}_{2} \mathrm{O}_{3}\left(110{ }^{\circ} \mathrm{C}\right)$ previously reported by our group (Yasuda et al., 2012). Therefore, to increase the catalytic activity of $11 \mathrm{Co} / \mathrm{CZS} / \mathrm{Al}_{2} \mathrm{O}_{3}$, a small amount of platinum $(1 \mathrm{wt} \%)$ was additionally supported on the surface of the catalyst. 


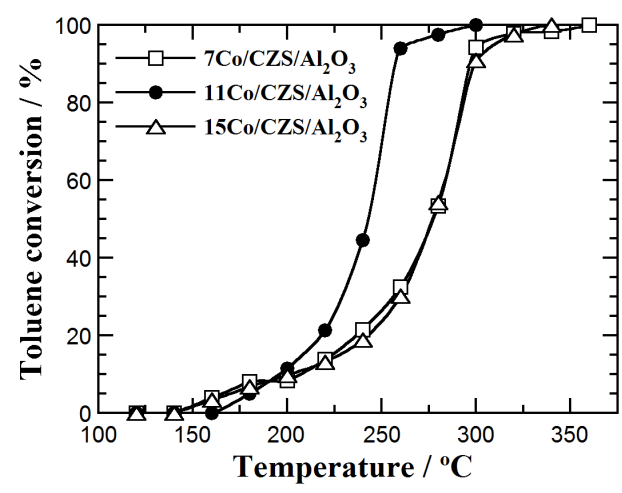

Figure 2. Temperature dependencies of toluene oxidation on the

(a) $7 \mathrm{wt} \% \mathrm{Co}_{3} \mathrm{O}_{4} / 16 \mathrm{wt} \% \mathrm{Ce}_{0.62} \mathrm{Zr}_{0.20} \mathrm{Sn}_{0.18} \mathrm{O}_{2.0} / \gamma-\mathrm{Al}_{2} \mathrm{O}_{3}$, (b) $11 \mathrm{wt} \% \mathrm{Co}_{3} \mathrm{O}_{4} / 16 \mathrm{wt} \% \mathrm{Ce}_{0.62} \mathrm{Zr}_{0.20} \mathrm{Sn}_{0.18} \mathrm{O}_{2.0} / \gamma-\mathrm{Al}_{2} \mathrm{O}_{3}$, and (c) $15 \mathrm{wt} \% \mathrm{Co}_{3} \mathrm{O}_{4} / 16 \mathrm{wt} \% \mathrm{Ce}_{0.62} \mathrm{Zr}_{0.20} \mathrm{Sn}_{0.18} \mathrm{O}_{2.0} / \gamma-\mathrm{Al}_{2} \mathrm{O}_{3}$ catalysts

Figure 3 shows XRD patterns of $1 \mathrm{wt} \% \mathrm{Pt} / 11 \mathrm{wt} \% \mathrm{Co}_{3} \mathrm{O}_{4} / 16 \mathrm{wt} \% \mathrm{Ce}_{0.62} \mathrm{Zr}_{0.20} \mathrm{Sn}_{0.18} \mathrm{O}_{2.00} / \gamma-\mathrm{Al}_{2} \mathrm{O}_{3}$ $\left(1 \mathrm{Pt} / 11 \mathrm{Co} / \mathrm{CZS} / \mathrm{Al}_{2} \mathrm{O}_{3}\right)$ and $1 \mathrm{wt} \% \mathrm{Pt} / 16 \mathrm{wt} \% \mathrm{Ce}_{0.62} \mathrm{Zr}_{0.20} \mathrm{Sn}_{0.18} \mathrm{O}_{2.00} / \gamma-\mathrm{Al}_{2} \mathrm{O}_{3}\left(1 \mathrm{Pt} / \mathrm{CZS} / \mathrm{Al}_{2} \mathrm{O}_{3}\right)$. In addition, in these cases, only $\mathrm{Ce}_{0.62} \mathrm{Zr}_{0.20} \mathrm{Sn}_{0.18} \mathrm{O}_{2.00}, \mathrm{Co}_{3} \mathrm{O}_{4}$, and $\gamma-\mathrm{Al}_{2} \mathrm{O}_{3}$ were observed in the XRD patterns and no peaks corresponding to platinum appeared probably due to the small platinum particles that are highly dispersed on the surface of the catalysts.

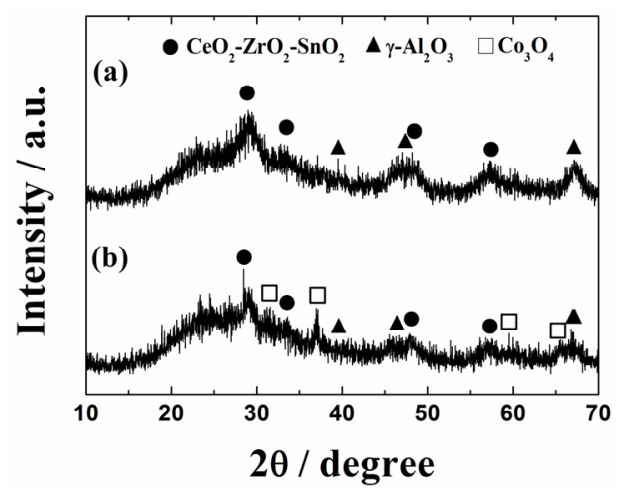

Figure 3. XRD patterns of the (a) $1 \mathrm{wt} \% \mathrm{Pt} / 16 \mathrm{wt} \% \mathrm{Ce}_{0.62} \mathrm{Zr}_{0.20} \mathrm{Sn}_{0.18} \mathrm{O}_{2.0} / \gamma-\mathrm{Al}_{2} \mathrm{O}_{3}$ and (b) $1 \mathrm{wt} \% \mathrm{Pt} / 11 \mathrm{wt} \% \mathrm{Co}_{3} \mathrm{O}_{4}$ $/ 16 \mathrm{wt} \% \mathrm{Ce}_{0.62} \mathrm{Zr}_{0.20} \mathrm{Sn}_{0.18} \mathrm{O}_{2.0} / \gamma-\mathrm{Al}_{2} \mathrm{O}_{3}$ catalysts $\left(\bullet: \mathrm{CeO}_{2}-\mathrm{ZrO}_{2}-\mathrm{SnO}_{2}, \boldsymbol{\Delta}: \gamma-\mathrm{Al}_{2} \mathrm{O}_{3}, \square: \mathrm{Co}_{3} \mathrm{O}_{4}\right)$

The bright and dark field TEM images of $1 \mathrm{Pt} / 11 \mathrm{Co} / \mathrm{CZS} / \mathrm{Al}_{2} \mathrm{O}_{3}$ and $1 \mathrm{Pt} / \mathrm{CZS} / \mathrm{Al}_{2} \mathrm{O}_{3}$ are depicted in Figure 4 . As shown by these photographs, there is no clear difference in the size and dispersion state of platinum particles in these catalysts, which are recognized as bright spots in the dark field images in Figures 4(b) and (d). The particle size of platinum was estimated using these spots and it was confirmed to be smaller than $5 \mathrm{~nm}$ for both catalysts. Furthermore, it is also found that $\mathrm{Co}_{3} \mathrm{O}_{4}$ is present as needle crystals by comparing the bright field image of $1 \mathrm{Pt} / 11 \mathrm{Co} / \mathrm{CZS} / \mathrm{Al}_{2} \mathrm{O}_{3}$ with that of $1 \mathrm{Pt} / \mathrm{CZS} / \mathrm{Al}_{2} \mathrm{O}_{3}$. BET specific surface areas of $1 \mathrm{Pt} / \mathrm{CZS} / \mathrm{Al}_{2} \mathrm{O}_{3}$ and $1 \mathrm{Pt} / 11 \mathrm{Co} / \mathrm{CZS} / \mathrm{Al}_{2} \mathrm{O}_{3}$ are also listed in Table 1 . The surface area of the latter is smaller than that of the former, which might be as a result of the $\mathrm{Co}_{3} \mathrm{O}_{4}$ deposition in the pore of $\mathrm{CZS} / \mathrm{Al}_{2} \mathrm{O}_{3}$, as mentioned above. 


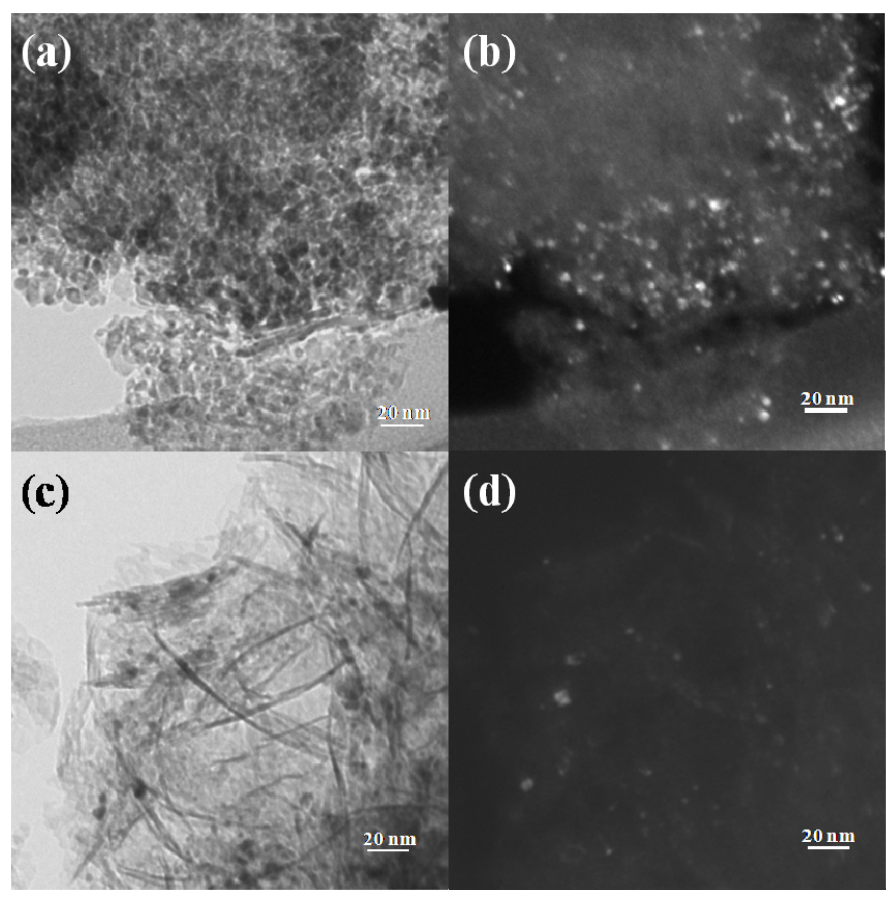

Figure 4. Transmission electron micrographs (TEM) of the (a), (b) $1 \mathrm{wt} \% \mathrm{Pt} / 16 \mathrm{wt} \% \mathrm{Ce}_{0.62} \mathrm{Zr}_{0.20} \mathrm{Sn}_{0.18} \mathrm{O}_{2.0} / \gamma-\mathrm{Al}_{2} \mathrm{O}_{3}$, and (c), (d) $1 \mathrm{wt} \% \mathrm{Pt} / 11 \mathrm{wt} \% \mathrm{Co}_{3} \mathrm{O}_{4} / 16 \mathrm{wt} \% \mathrm{Ce}_{0.62} \mathrm{Zr}_{0.20} \mathrm{Sn}_{0.18} \mathrm{O}_{2.0} / \gamma-\mathrm{Al}_{2} \mathrm{O}_{3}$ catalysts: (a), (c) are bright field images, and (b), (d) are dark field images

The BJH desorption pore size distribution plots of $1 \mathrm{Pt} / \mathrm{CZS} / \mathrm{Al}_{2} \mathrm{O}_{3}$ and $1 \mathrm{Pt} / 11 \mathrm{Co} / \mathrm{CZS} / \mathrm{Al}_{2} \mathrm{O}_{3}$ are shown in Figure 5. As evidenced in this figure, these catalyst particles have a narrow mesopore size distribution at $6 \mathrm{~nm}$ and the size was maintained even if $\mathrm{Co}_{3} \mathrm{O}_{4}$ was deposited on $\mathrm{Ce}_{0.62} \mathrm{Zr}_{0.20} \mathrm{Sn}_{0.18} \mathrm{O}_{2.0} / \gamma-\mathrm{Al}_{2} \mathrm{O}_{3}$. However, the pore volume was significantly decreased by the $\mathrm{Co}_{3} \mathrm{O}_{4}$ deposition, which supports the above discussion.

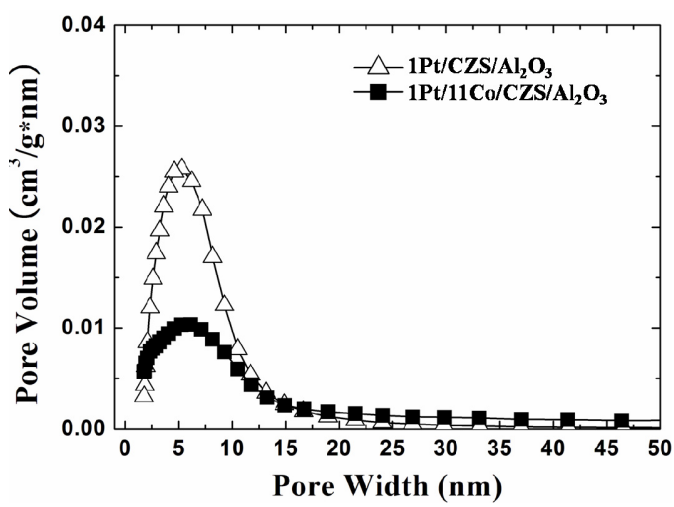

Figure 5. BJH pore distribution plots of the $1 \mathrm{wt} \% \mathrm{Pt} / 16 \mathrm{wt} \% \mathrm{Ce}_{0.62} \mathrm{Zr}_{0.20} \mathrm{Sn}_{0.18} \mathrm{O}_{2.0} / \gamma-\mathrm{Al}_{2} \mathrm{O}_{3}$ and $1 \mathrm{wt} \% \mathrm{Pt} / 11 \mathrm{wt} \% \mathrm{Co}_{3} \mathrm{O}_{4} / 16 \mathrm{wt} \% \mathrm{Ce}_{0.62} \mathrm{Zr}_{0.20} \mathrm{Sn}_{0.18} \mathrm{O}_{2.0} / \gamma-\mathrm{Al}_{2} \mathrm{O}_{3}$ catalysts.

Figure 6 shows the temperature dependencies of toluene oxidation over the $1 \mathrm{Pt} / 11 \mathrm{Co} / \mathrm{CZS} / \mathrm{Al}_{2} \mathrm{O}_{3}$ and $11 \mathrm{Co} / \mathrm{CZS} / \mathrm{Al}_{2} \mathrm{O}_{3}$ catalysts. Results for $1 \mathrm{Pt} / \mathrm{CZS} / \mathrm{Al}_{2} \mathrm{O}_{3}, 1 \mathrm{Pt} / 11 \mathrm{Co} / \mathrm{Al}_{2} \mathrm{O}_{3}$, and conventional $5 \mathrm{wt} \% \mathrm{Pt} / \gamma-\mathrm{Al}_{2} \mathrm{O}_{3}$ are also plotted for comparison. The total oxidation of toluene to $\mathrm{CO}_{2}$ and water vapor was confirmed for all catalysts. The toluene oxidation activity of $11 \mathrm{Co} / \mathrm{CZS} / \mathrm{Al}_{2} \mathrm{O}_{3}$ was significantly enhanced by the addition of platinum, and despite a smaller platinum loading in the present catalysts, toluene was completely oxidized at a lower temperature of $160{ }^{\circ} \mathrm{C}$ compared to that using $5 \mathrm{wt} \% \mathrm{Pt} / \gamma-\mathrm{Al}_{2} \mathrm{O}_{3}\left(170{ }^{\circ} \mathrm{C}\right)$. Furthermore, the present $1 \mathrm{Pt} / 11 \mathrm{Co} / \mathrm{CZS} / \mathrm{Al}_{2} \mathrm{O}_{3}$ catalyst (complete oxidation of toluene at $160{ }^{\circ} \mathrm{C}$ ) is more active than $1 \mathrm{Pt} / \mathrm{CZS} / \mathrm{Al}_{2} \mathrm{O}_{3}$ $\left(180{ }^{\circ} \mathrm{C}\right)$, indicating the advantage of $\mathrm{Co}_{3} \mathrm{O}_{4}$ addition to $\mathrm{CZS} / \mathrm{Al}_{2} \mathrm{O}_{3}$. However, the presence of $\mathrm{CZS}$ is 
indispensable because the oxidation activity of $1 \mathrm{Pt} / 11 \mathrm{Co} / \mathrm{Al}_{2} \mathrm{O}_{3} \quad\left(210{ }^{\circ} \mathrm{C}\right)$ is smaller than that of $1 \mathrm{Pt} / 11 \mathrm{Co} / \mathrm{CZS} / \mathrm{Al}_{2} \mathrm{O}_{3}\left(160^{\circ} \mathrm{C}\right)$.

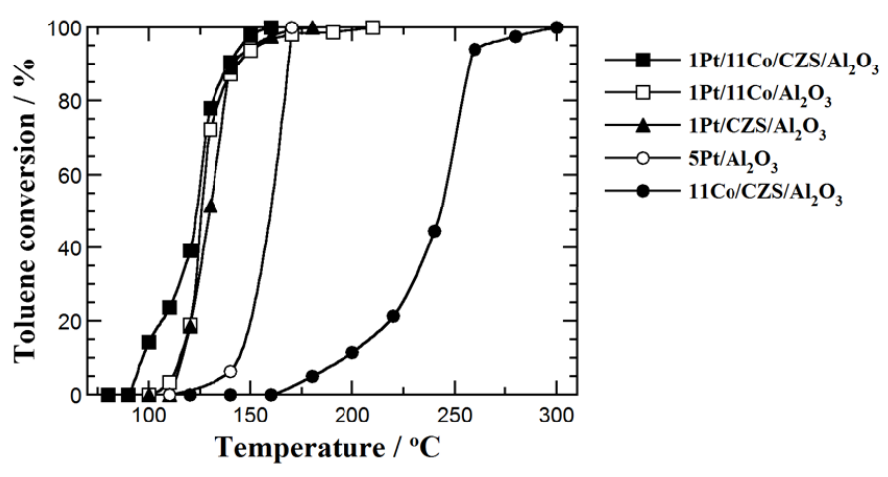

Figure 6. Temperature dependencies of toluene oxidation on the

$1 \mathrm{wt} \% \mathrm{Pt} / 11 \mathrm{wt} \% \mathrm{Co}_{3} \mathrm{O}_{4} / 16 \mathrm{wt} \% \mathrm{Ce}_{0.62} \mathrm{Zr}_{0.20} \mathrm{Sn}_{0.18} \mathrm{O}_{2.0} / \gamma-\mathrm{Al}_{2} \mathrm{O}_{3}(\mathbf{m}), 11 \mathrm{wt} \% \mathrm{Co}_{3} \mathrm{O}_{4} / 16 \mathrm{wt} \% \mathrm{Ce}_{0.62} \mathrm{Zr}_{0.20} \mathrm{Sn}_{0.18} \mathrm{O}_{2.0} / \gamma-\mathrm{Al}_{2} \mathrm{O}_{3}$ $(\bullet), 1 \mathrm{wt} \% \mathrm{Pt} / 16 \mathrm{wt} \% \mathrm{Ce}_{0.62} \mathrm{Zr}_{0.20} \mathrm{Sn}_{0.18} \mathrm{O}_{2.0} / \gamma-\mathrm{Al}_{2} \mathrm{O}_{3}(\boldsymbol{\Delta}), 1 \mathrm{wt} \% \mathrm{Pt} / 11 \mathrm{wt} \% \mathrm{Co}_{3} \mathrm{O}_{4} / \gamma-\mathrm{Al}_{2} \mathrm{O}_{3}(\square)$, and $5 \mathrm{wt} \% \mathrm{Pt} / \gamma-\mathrm{Al}_{2} \mathrm{O}_{3}$

(०) catalysts

In addition, a supported platinum catalyst was also prepared at $450{ }^{\circ} \mathrm{C}$. The temperature dependencies of toluene oxidation on the $1 \mathrm{wt} \% \mathrm{Pt} / 11 \mathrm{wt} \% \mathrm{Co}_{3} \mathrm{O}_{4} / 16 \mathrm{wt} \% \mathrm{Ce}_{0.62} \mathrm{Zr}_{0.20} \mathrm{Sn}_{0.18} \mathrm{O}_{2.0} / \gamma-\mathrm{Al}_{2} \mathrm{O}_{3}$ catalysts calcined at 450 and $500{ }^{\circ} \mathrm{C}$ is shown in Figure 7. Unfortunately, the oxidation activity was not improved. Therefore, the calcination temperature of $500{ }^{\circ} \mathrm{C}$ is appropriate for the supported platinum catalyst.

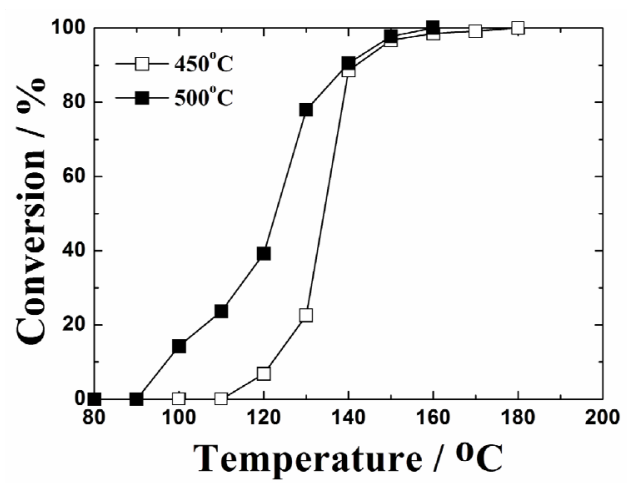

Figure 7. Temperature dependencies of toluene oxidation on the

$1 \mathrm{wt} \% \mathrm{Pt} / 11 \mathrm{wt} \% \mathrm{Co}_{3} \mathrm{O}_{4} / 16 \mathrm{wt} \% \mathrm{Ce}_{0.62} \mathrm{Zr}_{0.20} \mathrm{Sn}_{0.18} \mathrm{O}_{2.0} / \gamma-\mathrm{Al}_{2} \mathrm{O}_{3}$ catalysts calcined at $450{ }^{\circ} \mathrm{C}(\square)$ and $500{ }^{\circ} \mathrm{C}(\mathbf{m})$

To identify the cause for the positive effect of $\mathrm{Co}_{3} \mathrm{O}_{4}$, TPR spectra of $11 \mathrm{Co} / \mathrm{CZS} / \mathrm{Al}_{2} \mathrm{O}_{3}$ and $\mathrm{CZS} / \mathrm{Al}_{2} \mathrm{O}_{3}$ are measured and their oxygen release behaviors were compared as shown in Figure 8. In the case of $\mathrm{CZS} / \mathrm{Al}_{2} \mathrm{O}_{3}$, the oxygen release peak was observed at $92{ }^{\circ} \mathrm{C}$, while the peak appeared at a lower temperature of $78{ }^{\circ} \mathrm{C}$ for $11 \mathrm{Co} / \mathrm{CZS} / \mathrm{Al}_{2} \mathrm{O}_{3}$. Accordingly, the introduction of $\mathrm{Co}_{3} \mathrm{O}_{4}$ on the $\mathrm{CZS} / \mathrm{Al}_{2} \mathrm{O}_{3}$ support was remarkably effective in enhancing the oxygen supply capability at low temperatures. Furthermore, the total oxygen storage capacity of $11 \mathrm{Co} / \mathrm{CZS} / \mathrm{Al}_{2} \mathrm{O}_{3}$ was $388 \mu$ mol O $\mathrm{O}_{2} \mathrm{~g}^{-1}$, which was 2.5 times larger than that of $\mathrm{CZS} / \mathrm{Al}_{2} \mathrm{O}_{3}\left(140 \mu \mathrm{mol} \mathrm{O} \mathrm{g}^{-1}\right)$. The increase in the oxygen release and storage abilities was due to the synergistic effects of three redox couples of $\mathrm{Ce}^{4+} / \mathrm{Ce}^{3+}, \mathrm{Sn}^{4+} / \mathrm{Sn}^{2+}$, and $\mathrm{Co}^{3+} / \mathrm{Co}^{2+}$, whereby the toluene oxidation was facilitated. As a result, the introduction of $\mathrm{Co}_{3} \mathrm{O}_{4}$ as a promoter was highly effective in enhancing the catalytic activity. 


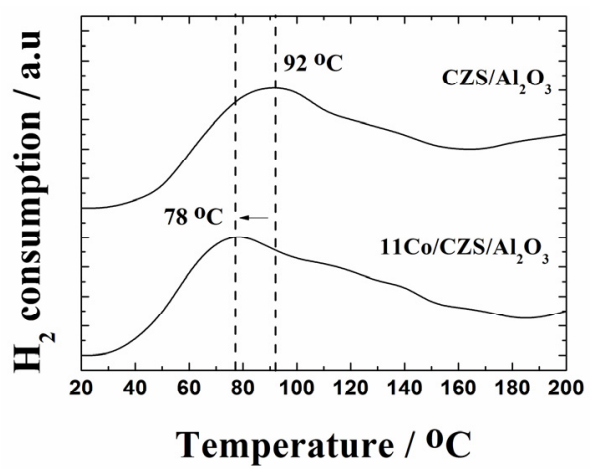

Figure 8. TPR profiles of the $16 \mathrm{wt} \% \mathrm{Ce}_{0.62} \mathrm{Zr}_{0.20} \mathrm{Sn}_{0.18} \mathrm{O}_{2.0} / \gamma-\mathrm{Al}_{2} \mathrm{O}_{3}$ and $11 \mathrm{wt} \% \mathrm{Co}_{3} \mathrm{O}_{4} / 16 \mathrm{wt} \% \mathrm{Ce}_{0.62} \mathrm{Zr}_{0.20} \mathrm{Sn}_{0.18} \mathrm{O}_{2.0} / \gamma-\mathrm{Al}_{2} \mathrm{O}_{3}$ catalysts

The oxidation states of $\mathrm{Ce}, \mathrm{Sn}, \mathrm{Co}$, and $\mathrm{Pt}$ in the $1 \mathrm{Pt} / 11 \mathrm{Co} / \mathrm{CZS} / \mathrm{Al}_{2} \mathrm{O}_{3}$ catalyst were analyzed by XPS. The XPS results of Ce 3d, Sn 3d, Co 2p, and Pt 4f core-levels are shown in Figure 9. From Figures 9(a) and (b), it is evident that cerium exists both in the trivalent and tetravalent states (Beche et al., 2008; Ma et al., 2009), while tin remains in the tetravalent state and no peaks of the $\mathrm{Sn}^{2+}$ species are observed (Kover et al., 1995; Yasuda et al., 2012). In the case of cobalt, the Co $2 p$ peaks in Figure 9(c) are deconvoluted into five peaks. The Co $2 p_{3 / 2}$ and $2 \mathrm{p}_{3 / 2}$ peaks can be attributed to the divalent $\left(\mathrm{Co}^{2+}: 780.8\right.$ and $\left.796.3 \mathrm{eV}\right)$ and trivalent $\left(\mathrm{Co}^{3+}: 779.5\right.$ and 794.5 $\mathrm{eV}$ ) oxidation states, and the broad one at $786.0 \mathrm{eV}$ corresponds to a satellite peak of $\mathrm{Co}^{2+}$ (Liotta et al., 2006; Xiao et al., 2008). These are the typical results for $\mathrm{Co}_{3} \mathrm{O}_{4}$ (Liotta et al., 2009). The $\mathrm{Pt} 4 \mathrm{f}$ peaks are shown in Figure 9(d). Although the $\mathrm{Pt} 4 \mathrm{f}_{5 / 2}$ peak at $74.4 \mathrm{eV}$ overlaps that of $\mathrm{Al} 2 \mathrm{p}$ in the present case, the small $\mathrm{Pt} 4 \mathrm{f}_{7 / 2}$ peak is clearly observed at $70.9 \mathrm{eV}$, which can be attributed to the metallic platinum ( $\mathrm{Pt}^{0}$ ) (Zhang et al., 2003).

Taking into account of the catalysis, TPR, and XPS results, the high oxidation activity of toluene observed in $1 \mathrm{Pt} / 11 \mathrm{Co} / \mathrm{CZS} / \mathrm{Al}_{2} \mathrm{O}_{3}$ can be attributed to a concerted effect of $\mathrm{Pt}, \mathrm{Co}_{3} \mathrm{O}_{4}$, and $\mathrm{Ce}_{0.62} \mathrm{Zr}_{0.20} \mathrm{Sn}_{0.18} \mathrm{O}_{2.0}$ supported on $\gamma-\mathrm{Al}_{2} \mathrm{O}_{3}$. The readily reducible $\mathrm{Co}_{3} \mathrm{O}_{4}$ and $\mathrm{Ce}_{0.62} \mathrm{Zr}_{0.20} \mathrm{Sn}_{0.18} \mathrm{O}_{2.0}$ contribute to the supplementation of active oxygen species from the catalyst bulk, and the oxygen reacts with toluene at the interface of three $\mathrm{Pt}, \mathrm{Co}_{3} \mathrm{O}_{4}$, and $\mathrm{Ce}_{0.62} \mathrm{Zr}_{0.20} \mathrm{Sn}_{0.18} \mathrm{O}_{2.0}$ phases. As a result, complete toluene oxidation was realized using the present $1 \mathrm{Pt} / 11 \mathrm{Co} / \mathrm{CZS} / \mathrm{Al}_{2} \mathrm{O}_{3}$ catalyst at a temperature of $160{ }^{\circ} \mathrm{C}$ which is lower than that of $5 \mathrm{wt} \% \mathrm{Pt} / \gamma-\mathrm{Al}_{2} \mathrm{O}_{3}\left(170{ }^{\circ} \mathrm{C}\right)$, in spite of a smaller amount of platinum.
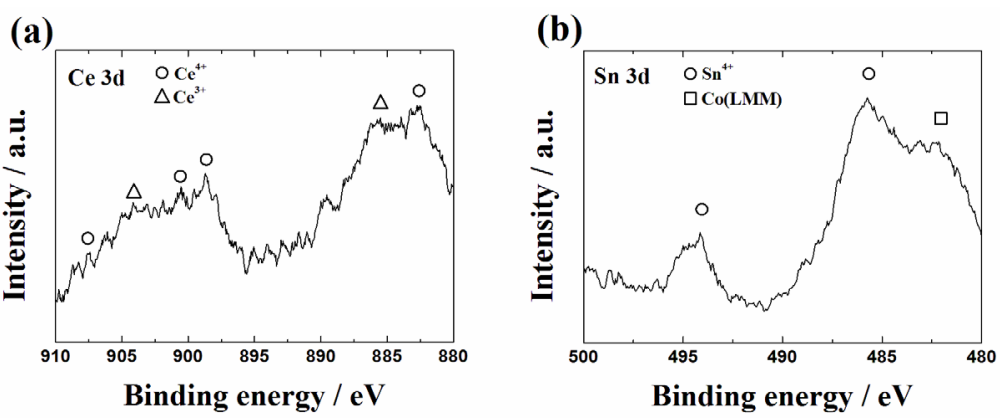

(c)
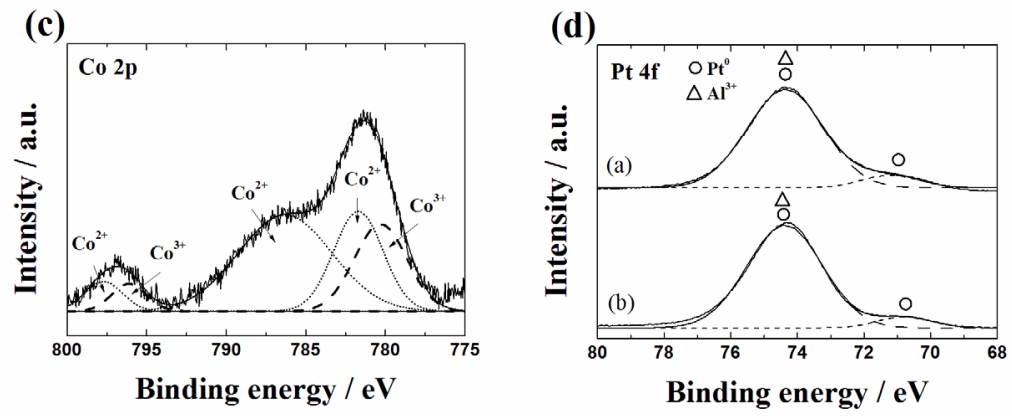

Figure 9. XPS results of the $1 \mathrm{wt} \% \mathrm{Pt} / 11 \mathrm{wt} \% \mathrm{Co}_{3} \mathrm{O}_{4} / 16 \mathrm{wt} \% \mathrm{Ce}_{0.62} \mathrm{Zr}_{0.20} \mathrm{Sn}_{0.18} \mathrm{O}_{2.0} / \gamma-\mathrm{Al}_{2} \mathrm{O}_{3}$ catalyst : (a) Ce $3 \mathrm{~d}$, (b) Sn 3d, (c) Co 2p, and (d) Pt 4f core-levels 


\section{Conclusions}

$\mathrm{Co}_{3} \mathrm{O}_{4} / \mathrm{CeO}_{2}-\mathrm{ZrO}_{2}-\mathrm{SnO}_{2} / \gamma-\mathrm{Al}_{2} \mathrm{O}_{3}$ and $\mathrm{Pt} / \mathrm{Co}_{3} \mathrm{O}_{4} / \mathrm{CeO}_{2}-\mathrm{ZrO}_{2}-\mathrm{SnO}_{2} / \gamma-\mathrm{Al}_{2} \mathrm{O}_{3}$ catalysts were successfully prepared by the conventional co-precipitation and impregnation methods. The catalytic tests for toluene oxidation on these materials showed that addition of $\mathrm{Co}_{3} \mathrm{O}_{4}$ to a $\mathrm{Pt} / \mathrm{CeO}_{2}-\mathrm{ZrO}_{2}-\mathrm{SnO}_{2} / \gamma-\mathrm{Al}_{2} \mathrm{O}_{3}$ catalyst was significantly effective in decreasing the amount of platinum without significant reduction in the activity. In fact, complete oxidation of toluene was realized using the $1 \mathrm{wt} \% \mathrm{Pt} / 11 \mathrm{wt} \% \mathrm{Co}_{3} \mathrm{O}_{4} / 16 \mathrm{wt} \% \mathrm{Ce}_{0.62} \mathrm{Zr}_{0.20} \mathrm{Sn}_{0.18} \mathrm{O}_{2.0} / \gamma-\mathrm{Al}_{2} \mathrm{O}_{3}$ catalyst at $160{ }^{\circ} \mathrm{C}$, which was lower than that using the $5 \mathrm{wt} \% \mathrm{Pt} / \gamma-\mathrm{Al}_{2} \mathrm{O}_{3}$ catalyst $\left(170{ }^{\circ} \mathrm{C}\right)$. Since the oxidation activities of $1 \mathrm{wt} \% \mathrm{Pt} / 16 \mathrm{wt} \% \mathrm{Ce}_{0.62} \mathrm{Zr}_{0.20} \mathrm{Sn}_{0.18} \mathrm{O}_{2.00} / \gamma-\mathrm{Al}_{2} \mathrm{O}_{3}$ and $1 \mathrm{wt} \% \mathrm{Pt} / 11 \mathrm{wt} \% \mathrm{Co}_{3} \mathrm{O}_{4} / \gamma-\mathrm{Al}_{2} \mathrm{O}_{3}$ were lower than that of $1 \mathrm{wt} \% \mathrm{Pt} / 11 \mathrm{wt} \% \mathrm{Co}_{3} \mathrm{O}_{4} / 16 \mathrm{wt} \% \mathrm{Ce}_{0.62} \mathrm{Zr}_{0.20} \mathrm{Sn}_{0.18} \mathrm{O}_{2.0} / \gamma-\mathrm{Al}_{2} \mathrm{O}_{3}$, the cause for the high toluene oxidation activity observed in the $1 \mathrm{wt} \% \mathrm{Pt} / 11 \mathrm{wt} \% \mathrm{Co}_{3} \mathrm{O}_{4} / 16 \mathrm{wt} \% \mathrm{Ce}_{0.62} \mathrm{Zr}_{0.20} \mathrm{Sn}_{0.18} \mathrm{O}_{2.0} / \gamma-\mathrm{Al}_{2} \mathrm{O}_{3}$ catalyst can be attributed to the concerted effect of $\mathrm{Pt}, \mathrm{Co}_{3} \mathrm{O}_{4}$, and $\mathrm{Ce}_{0.62} \mathrm{Zr}_{0.20} \mathrm{Sn}_{0.18} \mathrm{O}_{2.0}$ supported on $\gamma-\mathrm{Al}_{2} \mathrm{O}_{3}$.

\section{Acknowledgements}

This study was partially supported by the Industrial Technology Research Grant Program '08 (Project ID: 08B42001a) from the New Energy and Industrial Technology Development Organization (NEDO) of Japan, and the Environment Research and Technology Development Fund (B-0907) of the Ministry of the Environment, Japan.

\section{References}

Atkinson, R., \& Arey, J. (2003). Atmospheric degradation of volatile organic compounds. Chemical Reviews, 103, 4605-4638. http://dx.doi.org/10.1021/cr0206420

Beche, E., Charvin, P., Perarnau, D., Abanades, S., \& Flamant, G. (2008). Ce 3d XPS investigation of cerium oxides and mixed cerium oxide $\left(\mathrm{Ce}_{x} \mathrm{Ti}_{y} \mathrm{O}_{z}\right)$. Surface and Interface Analysis, 40, 264-267. http://dx.doi.org/10.1002/sia.2686

Chianelli, R. R., Berhault, G., \& Torres, B. (2009). Unsupported transition metal sulfide catalysts: 100 years of science and application. Catalysis Today, 147, 275-286. http://dx.doi.org/10.1016/j.cattod.2008.09.041

Einaga, H., Futamura, S., \& Ibusuki, T. (2002). Heterogeneous photocatalytic oxidation of benzene, toluene, cyclohexene and cyclohexane in humidified air: comparison of decomposition behavior on photoirradiated $\mathrm{TiO}_{2} \quad$ catalyst. Applied Catalysis B: Environmental, 38, 215-225. http://dx.doi.org/10.1016/S0926-3373(02)00056-5

Hamins, A., \& Seshadri, K. (1987). The structure of diffusion flames burning pure, binary, and ternary solutions of methanol heptane and toluene. Combustion and Flame, 68, 295-307. http://dx.doi.org/10.1016/0010-2180(87)90006-X

Harling, A. M., Glover, D. J., Whitehead, J. C., \& Zhang, K. (2009). The role of ozone in the plasma-catalytic destruction of environmental pollutants. Applied Catalysis B: Environmental, 90, 157-161. http://dx.doi.org/ 10.1016/j.apcatb.2009.03.005

Hauxell, F., \& Ottewill, R. H. (1968). The adsorption of toluene vapor on water surfaces. Journal of Colloid and Interface Science, 28, 514-521. http://dx.doi.org/10.1016/0021-9797(68)90084-2

Imanaka, N., Masui, T., Minami, K., \& Koyabu, K. (2005). Promotion of low-temperature reduction behavior of the $\mathrm{CeO}_{2}-\mathrm{ZrO}_{2}-\mathrm{Bi}_{2} \mathrm{O}_{3}$ solid solution by addition of silver. Chemistry Materials, 17, 6511-6513. http://dx.doi.org/10.1021/cm0519380

Imanaka, N., Masui, T., Koyabu, K., Minami, K., \& Egawa, T. (2007). Significant low-temperature redox activity of $\mathrm{Ce}_{0.64} \mathrm{Zr}_{0.16} \mathrm{Bi}_{0.20} \mathrm{O}_{1.90}$ supported on $\gamma-\mathrm{Al}_{2} \mathrm{O}_{3}$. Advanced Materials, 19, 1608-1611. http://dx.doi.org/10.1002/adma.200502741

Imanaka, N., Masui, T., Terada, A., \& Imadzu, H. (2008). Complete oxidation of ethylene at temperatures below $100{ }^{\circ} \mathrm{C}$ over a $\mathrm{Pt} / \mathrm{Ce}_{0.64} \mathrm{Zr}_{0.16} \mathrm{Bi}_{0.20} \mathrm{O}_{1.90} / \gamma-\mathrm{Al}_{2} \mathrm{O}_{3}$ catalyst. Chemistry Letters, 37, 42-43. http://dx.doi.org/10.1246/cl.2008.42

Imanaka, N., \& Masui, T. (2009). Advanced materials for environmental catalysts. Chemical Record, 9, 40-50. http://dx.doi.org/10.1002/tcr.20167

Imanaka, N., Masui, T., \& Yasuda, K. (2011). Environmental catalysts for complete oxidatioin of volatile organic compounds and methane. Chemistry Letters, 40, 780-785. http://dx.doi.org/10.1246/c1.2011.780

Kover, L., Kovacs, Zs., Sanjines, R., Mretti, G., Cserny, I., Margaritondo, G., ... Adachi, H. (1995). Electronic structure of tin oxides: High-resolution study of XPS and auger spectra. Surface and Interface Analysis, 23, 
461-466. http://dx.doi.org/10.1002/sia.740230705

Lamonier, J. F., Boutoundou, A. B., Gennequin, C., Perez-Zurita, M. J., Siffert, S., \& Aboukais, A. (2007). Catalytic removal of toluene in air over Co-Mn-Al nano-oxides synthesized by hydrotalcite route. Catalysis Letters, 118, 165-172. http://dx.doi.org/10.1007/s10562-007-9196-4

Liotta, L. F., Di Carlo, G., Pantaleo, G., Venezia, A. M., \& Danello, G. (2006). $\mathrm{Co}_{3} \mathrm{O}_{4} / \mathrm{CeO}_{2}$ composite oxides for methane emissions abatement: Relationship between $\mathrm{Co}_{3} \mathrm{O}_{4}-\mathrm{CeO}_{2}$ interaction and catalytic activity. Applied Catalysis B: Environmental, 66, 217-227. http://dx.doi.org/10.1016/j.apcatb.2006.03.018

Liotta, L. F., Ousmane, M., Carlo, G. D., Pantaleo, G., Deganello, G., Boreave, A., \& Fendler, A. G. (2009). Catalytic removal of toluene over $\mathrm{Co}_{3} \mathrm{O}_{4}-\mathrm{CeO}_{2}$ mixed oxide catalysts: Comparison with $\mathrm{Pt} / \mathrm{Al}_{2} \mathrm{O}_{3}$. Catalysis Letters, 127, 270-276. http://dx.doi.org/ 10.1007/s10562-008-9640-0

Ma, Y., Ge, Q., Li, W., \& Xu, H. (2009). Methanol synthesis from sulfur-containing syngas over $\mathrm{Pd} / \mathrm{CeO}_{2}$ catalyst. Applied Catalysis B: Environmental, 90, 99-104. http://dx.doi.org/ 10.1016/j.apcatb.2009.02.020

Masui, T., Minami, K., Koyabu, K., \& Imanaka, N. (2006). Synthesis and characterisation of new promoters based on $\mathrm{CeO}_{2}-\mathrm{ZrO}_{2}-\mathrm{Bi}_{2} \mathrm{O}_{3}$ for automotive exhaust catalysts. Catalysis Today, 117, 187-192. http://dx.doi.org/ 10.1016/j.cattod.2006.05.015

Masui, T., Koyabu, K., Minami, K., Egawa, T., \& Imanaka, N. (2007). Low-temperature redox activity of $\mathrm{Ce}_{0.64} \mathrm{Zr}_{0.16} \mathrm{Bi}_{0.20} \mathrm{O}_{1.90} / \gamma-\mathrm{Al}_{2} \mathrm{O}_{3}$ and $\mathrm{Ag} / \mathrm{Ce}_{0.64} \mathrm{Zr}_{0.16} \mathrm{Bi}_{0.20} \mathrm{O}_{1.90} / \gamma-\mathrm{Al}_{2} \mathrm{O}_{3}$ catalysts. The Journal of Physical Chemistry C, 111, 13892-13897. http://dx.doi.org/ 10.1021/jp072634z

Masui, T., Imadzu, H., Mastuyama, N., \& Imanaka, N. (2010). Total oxidation of toluene on $\mathrm{Pt} / \mathrm{CeO}_{2}-\mathrm{ZrO}_{2}-\mathrm{Bi}_{2} \mathrm{O}_{3} / \gamma-\mathrm{Al}_{2} \mathrm{O}_{3}$ catalysts prepared in the presence of polyvinyl pyrrolidone. Journal of Hazardous Materials, 176, 1106-1109. http://dx.doi.org/10.1016/j.jhazmat.2009.11.108

Minami, K., Masui, T., Imanaka, N., Dai, L., \& Pacaud, B. (2006). Redox behavior of $\mathrm{CeO}_{2}-\mathrm{ZrO}_{2}-\mathrm{Bi}_{2} \mathrm{O}_{3}$ and $\mathrm{CeO}_{2}-\mathrm{ZrO}_{2}-\mathrm{Y}_{2} \mathrm{O}_{3}$ solid solutions at moderate temperatures. Journal of Alloys and Compounds, 408-412, 1132-1135. http://dx.doi.org/10.1016/j.jallcom.2004.12.141

Pedrosa, A. M. G., Souza, M. J. B., Fernandes, J. D. G., Melo, D. M. A., \& Araujo, A. S. (2003). n-Heptane oxidation over $\mathrm{Co}_{3} \mathrm{O}_{4}-\mathrm{CeO}_{2}$ catalyst. Reaction Kinetics and Catalysis Letters, 79, 391-396. http://dx.doi.org/10.1023/A:1024562924637

Ryerson, T. B., Trainer, M., Holloway, J. S., Parrish, D. D., Huey, L. G., Sueper, D. T., ... Fehsenfled, F. C. (2001). Observations of ozone formation in power plant plumes and implication for ozone control strategies. Science, 292, 719-723. http://dx.doi.org/10.1126/science.1058113

Rybak, P., Tomaszewska, B., Machocki, A., Grzegorczyk, W., \& Denis, A. (2011). Conversion of ethanol over supported cobalt oxide catalysts. Catalsis Today, 176, 14-20. http://dx.doi.org/10.1016/j.cattod.2011.06.015

Sungkono, I. E., Kameyama, H., \& Koya, T. (1997). Development of catalytic combustion technology of VOC materials by anodic oxidation catalyst. Applied Surface Science, 121/122, 425-428. http://dx.doi.org/10.1016/S0169-4332(97)00352-8

Spivey, J. J. (1987). Complete catalytic oxidation of volatile organics. Industrial and Engineering Chemistry Research, 26, 2165-2180. http://dx.doi.org/10.1021/ie00071a001

Saqer, S. M., Kondarides, D. I., \& Verykios, X. E. (2009). Catalytic activity of supported platinum and metal oxide catalysts for toluene oxidation. Topics in Catalysis, 52, 517-527. http://dx.doi.org/10.1007/s11244-009-9182-8

Wyrwalski, F., Giraudon, J. M., \& Lamonier, J. F. (2010). Synergistic coupling of the redox properties of supports and cobalt oxide $\mathrm{Co}_{3} \mathrm{O}_{4}$ for the complete oxidation of volatile organic compounds. Catalysis Letters, 137, 141-149. http://dx.doi.org/10.1007/s10562-010-0356-6

Xiao, Q., Zhang, J., Xiao, C., \& Tan, X. (2008). Photocatalytic degradation of methylene blue over $\mathrm{Co}_{3} \mathrm{O}_{4} / \mathrm{Bi}_{2} \mathrm{WO}_{6}$ composite under visible light irradiation. Catalysis Communications, 9, 1247-1253. http://dx.doi.org/10.1016/j.catcom.2007.11.011

Yasuda, K., Yoshimura, A., Katsuma, A., Masui, T., \& Imanaka, N. (2012). Low-temperature complete combustion of volatile organic compounds over novel $\mathrm{Pt} / \mathrm{CeO}_{2}-\mathrm{ZrO}_{2}-\mathrm{SnO}_{2} / \gamma-\mathrm{Al}_{2} \mathrm{O}_{3}$ catalysts. Bulletin of the Chemical Society of Japan, 85, 522-526. http://dx.doi.org/10.1246/bcsj.20110382

Zhang, X., \& Chan, K. (2003). Water-in-oil microemulsion synthesis of platinum-ruthenium nanoparticles their characterization and electrocatalytic properties. Chemistry of Materials, 15, 451-459. http://dx.doi.org/10.1021/cm0203868 